\title{
Recep Tayyip Erdoğan Üniversitesi Merkez Kampüsünde Elektromanyetik Alan Kirlilik Ölçümü ve Spektrum Analizi
}

\author{
Burak DİLEK ${ }^{1}$, Nilüfer AS ${ }^{1}$, Mustafa Ergin ŞAHIIN ${ }^{2 *}$ \\ ${ }^{1}$ Recep Tayyip Erdoğan Üniversitesi, Fen-Edebiyat Fakültesi, Fizik Bölümü, 53100 Rize, Türkiye \\ ${ }^{2}$ Recep Tayyip Erdoğan Üniversitesi, Mühendislik ve Mimarlık Fakültesi, Elektrik-Elektronik Bölümü, 53100, Rize, Türkiye \\ *Sorumlu Yazar/Corresponding Author \\ E-mail: mustafaerginsahin@yahoo.com \\ Arastırma makalesi/Research article \\ Geliş tarihi/Received:14.04.2021 \\ Orcid ID: 0000-0002-5121-6173 \\ Kabul tarihi/Accepted: 20.06.2021
}

\section{ÖZET}

Günümüzde hızla büyüyen teknoloji ile birlikte, elektromanyetik kirliliğin çevresel etkileri özellikle de insan sağlığına etkileri de artmıştır. Bu konuda yapılan çalışmalar artmakla birlikte bölgesel ya da noktasal ölçümler de daha bir anlam kazanmıştır. Bu çalışmada, ilk olarak Recep Tayyip Erdoğan Üniversitesi (RTEÜ) merkez kampüsünde elektromanyetik kirlilik değerleri incelenmiştir. Bu kapsamda, günün farklı saat dilimlerinde, 21 farklı noktada elektromanyetik kirlilik ölçümleri yapılmıştır. Bu ölçümler sırasında; $400 \mathrm{MHz}-6 \mathrm{GHz}$ bant aralığında çalışan kompakt bir spektrum analiz cihazı (SRM 3006) üç eksenli bir anten ile birlikte kullanılmıştır. Ölçüm sonuçları, uluslararası iyonize olmayan radyasyondan korunma komisyonu (ICNIRP) ve Bilgi Teknolojileri Kurumu (BTK) tarafından ilan edilen standart değerleri ile karşılaştırılmıştır. Elektromanyetik kirlilik oranı tehlikeli bir düzeyde bulunmamıştır. Çalışmanın devamında, ölçülen elektrik alan değerleri, bilgisayar programı ile kampüs koordinatlarına göre üç boyutlu grafik olarak elde edilmiştir. Hesaplama yöntemi kullanılarak yoğun elektromanyetik kirlilik bölgelerini gösteren veriler elde edilmiştir. Çalışmanın sonucunda, elektrik alan manyetik alan ve güç yoğunluklarının farklı ölçüm saatlerindeki değişimi grafiksel olarak gösterilmiştir. Ayrıca, elektromanyetik kirlilik seviyesinin diğer bölgelere göre daha yüksek olduğu kampüs bölgeleri de tespit edilmiş ve incelenmiş̦ir.

Anahtar Kelimeler: Elektromanyetik kirlilik ölçümü, RTEÜ kampüsü, Spektrum analizi, SAR değeri

\section{Electromagnetic Field Pollution Measurement and Spectrum Analysis at Recep Tayyip Erdogan University Main Campus}

\begin{abstract}
Electromagnetic pollution and its environmental effects, especially on human health, increased due to rapidly growing technology today. Studies on this subject have increased, and regional or point measurements have gained more importance. Electromagnetic pollution values in the central campus of RTE University were investigated in this study. In this context, electromagnetic pollution measurements were made at 21 different locations at certain times of the day. A compact spectrum analyzer device (SRM 3006) that covers a frequency range of $400 \mathrm{MHz}$ to $6 \mathrm{GHz}$ band was used together with its three-axis antenna during these measurements. The results of these measurements were compared with the standard values, which were declared by the International Commission on Non-Ionizing Radiation Protection (ICNIRP) and Information Technology Authority (BTK). The electromagnetic pollution rate has not been measured at a dangerous level. In addition to this study, measured electric field values were obtained as a three-dimensional graph for the campus coordinates by a computer program. Data showing the dense electromagnetic pollution regions were obtained using a developed calculation method. As the result of the study, electric field, magnetic field and power density variations at different measurement times are given graphically. Also, risky campus regions in terms of electromagnetic pollution were detected and investigated.
\end{abstract}

Keywords: Electromagnetic pollution measurements, RTEU campus, Spectrum analyser, SAR value.

Atıf için (Cite);

Dilek, B., As, N., Şahin, M.E. (2021). Recep Tayyip Erdoğan Üniversitesi Merkez Kampüsünde Elektromanyetik Alan Kirlilik Ölçümü ve Spektrum Analizi. Recep Tayyip Erdoğan Üniversitesi Fen ve Mühendislik Bilimleri Dergisi, 2(1), 53-65. 


\section{Giriş}

Günümüzde hızla gelişen ve hayatımızın bir parçası olan yeni teknolojik ürünler, elektromanyetik kirliliğin ana nedeni haline gelmiştir. Uluslararası bilim kuruluşları ve toplulukları bu konuyu mercek altına almış, bu kapsamda sınır değerler ve standartlar oluşturulmuştur (Bailey vd., 2019; ICNIRP, 1998). Özellikle kablosuz haberleşme sistemlerinin hizla artması ve elektromanyetik alanların sağlı riski oluşturması halkın ilgi odağı olmuştur. Çevredeki radyo frekansında (RF) elektromanyetik radyasyon artışı, araştırmacıları bu alanda araştırmalar yapmaya yönlendirmiştir (As vd., 2014; Ada, 2007; Bold vd., 2003). Elektromanyetik alanlar iyonlaşmaya sebep olmayan (non-ionizing) alanlar olarak adlandırılmaktadır. Elektromanyetik spektrumun kızıl ötesi bölgesinde yer alan ve mobil iletişimde kullanılan elektromanyetik dalgalar, günümüzde artan kullanım alanları sebebiyle çevredeki elektromanyetik alan kirliliğine oldukça fazla katkı yapmaktadır (Nilufer Belediyesi, 2007; Güler ve Çobanoğlu, 1994; Kamil, 2006). Bu dalgaların enerjisi en iyi su molekülleri tarafindan soğurulduğundan dörtte üçü su olan vücut hücrelerimizde 1s1 artışına sebep olmaktadır (URL-1; Hamid vd., 2006). İnsan vücudunda herhangi bir dokunun kendi iç sıcaklığının $0.5 \mathrm{C}^{\circ}$ den daha fazla artması o dokunun tahammül edemeyebileceği bir değer olarak alınmıştır. $\mathrm{Bu}$ değeri temel alarak geliştirilen bir sınır değer tüm vücut için ortalama özgül soğurma değeri olarak kabul edilmiştir (Baysal, 2011). Özellikle kan dolaşımı daha az olan göz, üreme hücreleri vb. 1s1l olarak daha çok etkilenmektedir (Şahin vd. 2011, 2013; Şeker ve Çerezci, 2000). Birçok laboratuvar çalışması ve epidemiyolojik araştırma elektromanyetik alanlara maruziyet ile ciddi sağlık problemleri arasındaki ilişkilerden söz etmektedir. Bağgsşıklık, sinir, nöroendokrin, üreme, kalp-damar sistemi ve kan parametreleri elektromanyetik alanlardan etkilenmektedirler (Sevgi, 2000a, 2000b; Özgür vd., 2015; Şehitoğlu vd., 2015).
Telekomünikasyon Kurumu tarafından 12.7.2001 tarihli resmi gazetede yayınlanan Yönetmelik ile Türkiye'de geçerli olan sınır değerleri belirlenmiştir. (Resmi Gazete, 2001). Türkiye'de 16 Mayıs 2009 tarihli resmi gazetede yayımlanan Yönetmelik ile BTK tek yetkili kurum haline getirilmiştir (Resmi Gazete, 2009). Elektromanyetik alanların insan sağlığına etkileri konusunda elektromanyetik alan ve güç yoğunluğuna ait sınır değerler uluslararası alanda dünya sağlık örgütü ve birçok kuruluşunda tercih ettiği en güvenilir otorite olan ICNIRP tarafından belirlenmiș ve kabul görmüştür (ICNIRP, 1998). Elektromanyetik kirliliğin insan yaşamındaki etkilerinin en aza indirilmesi için BTK tarafindan 27912 sayılı Resmi Gazetede yayınlanan yönetmeliğin 16. Madde' sine göre elektrik alan şiddeti, manyetik akı yoğunluğu ve güç yoğunluğu, ICNIRP in belirlediği limit değerin dörtte biri olarak belirlenmiştir (Resmi Gazete, 2011; TSE, 1996). ICNIRP limitleri; $900 \mathrm{MHz}$ için $41 \mathrm{~V} / \mathrm{m}, 1800 \mathrm{MHz}$ için 58 $\mathrm{V} / \mathrm{m}$ 'dir. Bu değerler, $\mathrm{ABD}$ ve Avrupa Birliği üyesi ülkeler dâhil 42 ülke tarafindan kabul edilmiş değerlerdir (ICNIRP, 1998). 17 Nisan 2018 gün ve 30394 sayılı resmi gazetede bu değerler daha da aşağı çekilerek ICNIRP in belirlediği değerlerin \%20 si olarak seçilmiştir (Resmi Gazete, 2018).

$\mathrm{Bu}$ konuda yapılan farklı çalışmalara bakıldığında, Adıyaman il merkezinde Atatürk Bulvarı boyunca $(5750 \mathrm{~m}) 250 \mathrm{~m}$ aralıklarla, 24 farklı yerlerde elektrik alan şiddeti (E), manyetik alan şiddeti $(H)$ ve eşdeğer düzlem dalga güç yoğunluğu (S) ölçümleri yapıldı. Seçilen yerlerde elektrik alan şiddetini, manyetik alan şiddetini ve güç yoğunluğunu ölçmek için, Spectran HF60105 V4 taşınabilir spektrum analizörü kullanıldı (Söğüt vd., 2017). Yine yapılan bir tez çalışmasında Kahramanmaraş il merkezinde elektromanyetik alan değerlerine ait ölçümler ve haritalama işlemi yapılmıştır (Şahin, 2016). Kılıç ve arkadaşları tarafindan yapılan bir çalışmada ise Cerrahpaşa Tıp Fakültesinin elektromanyetik alan haritası çıkarılmıştır 
(Kılıç, 2011). Seçilmiş bir pilot bölgede uzun süreli ve sürekli elektromanyetik kirlilik seviyelerinin ölçülmesi ve haritalanması için Malatya şehir merkezi ve yakın bölgelerinde bulunan baz istasyonlarının ve diğer elektromanyetik alan kaynaklarının yaydığ elektromanyetik alan şiddetlerinin dönemsel, frekans bazlı elektromanyetik alan yoğunluk ölçümleri yapılmış ve haritalandırılmıştır (Karadağ vd., 2014).

Yapılan bu çalışmada ise öncelikle kapsamlı bir literatür taramasının ardından elektromanyetik alanlar ve GSM sistemi hakkında genel bilgiler verilmiştir. Materyal ve yöntem kısmında ölçüm yapılacak alan, kullanılan yöntem ve ölçüm yapılacak frekans bilgileri hakkında bilgiler verilmiştir. Daha sonra ölçüm sistemi ve ölçüm yapma amaçlı kullanılan cihazın teknik özellikleri hakkında genel bilgiler verilmiştir. Analiz ve bulgular kısmında ise yapılan ölçümlerle ilgili örnek tablolar ve cihaz ekran görüntülerine yer verilerek ölçümlerin nasıl yapıldığg irdelenmiş verilen grafikler ile kampüs alanına ait günün belirli saatlerinde yirmi bir ayrı noktadaki ölçüm grafikleri verilerek bunlar detaylı olarak yorumlanmış ve yüksek çıkan değerlerin nedenleri üzerinde durulmuştur.

\section{Elektromanyetik Alanlar ve GSM Sistemi}

Elektromanyetik alanlar, yüklü parçacıkların hareketi sonucu oluşan ve birbirlerine dik doğrultularda titreşen değişken elektrik ve manyetik alanların her ikisine de dik doğrultudaki titreşimli yayılım alanlarıdır. Bu alanlar Şekil 1'deki gibi gösterilmektedirler (As vd., 2014; Dilek vd., 2013).

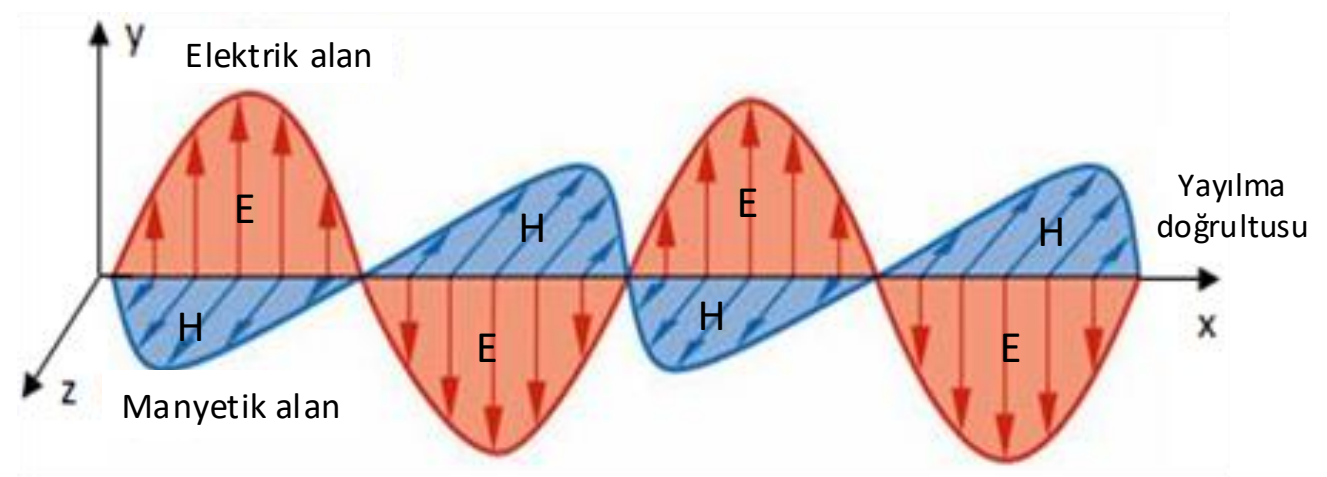

Şekil 1. Elektromanyetik dalga gösterimi

Figure 1. Electromagnetic wave representation

Elektromanyetik alanın elektrik ve manyetik alan bileşenlerinin birbirleri ve madde ile etkileşimleri Maxwell denklemleri adı verilen denklem seti ile incelenir (Karan ve As, 2016; Karan vd., 2017). Elektromanyetik alanlara ait elektrik ve manyetik bileşenlerinin konum ve zamana bağlı periyodik alan denklemleri Eşitlik 1 ve 2'deki gibidir. Elektromanyetik dalga denklemi ise, elektromanyetik dalgaların ortam boyunca ya da bir vakum ortamı içerisinde yayılmasını açıklayan, ikinci dereceden kısmi diferansiyel denklem şeklindedir ve elektrik alan $(E)$, ya da manyetik alan (B), cinsinden yazılabilir (Özdemir, 2001).

$$
\begin{aligned}
& E=E_{o} \sin (k x-\omega t) \\
& B=B_{o} \sin (k x-\omega t)
\end{aligned}
$$

Bir elektromanyetik dalgadaki enerji akış hızı Poynting vektörü $(S)$ ile tanımlanır. Birimi $\mathrm{J} / \mathrm{s} . \mathrm{m}^{2}$ 'dir. Poynting vektörünün büyüklüğü, akış yönüne dik olan birim yüzeyden, enerjinin geçiş hızını ifade etmektedir. $\mathrm{Bu}$ nedenle poynting vektörünün büyüklüğü, birim yüzey başına gücü ifade eder. $S$ vektörünün yönü, dalganın yayılma doğrultusu boyunca olup bu ifadelere ait eşitlikler Eşitlik 3-6 da verilmiştir. $S$ 'nin bu denklemleri zamanın her anında uygulanabilir ve enerjinin birim yüzeyden anlık geçme hızını ifade eder. 


$$
\begin{aligned}
& \mathrm{S}=\mathrm{ExH}=\mathrm{E} \cdot \mathrm{H} \\
& \mathrm{H}=\mathrm{E} / 377[\mathrm{~A} / \mathrm{m}] \\
& \mathrm{S}=\mathrm{E} \cdot \mathrm{H}=\mathrm{E}^{2} / 377 \\
& \mathrm{~S}=\mathrm{EB} / \mu\left[\mathrm{W} / \mathrm{m}^{2}\right]
\end{aligned}
$$

Elektromanyetik alanların çok geniş bir frekans aralığı vardır. Bu aralık; alçak frekanslı enerji iletim hatlarından, radyo ve görülebilir 1şık frekanslarına buradan da boyu bir metrenin trilyonda biri ile ifade edilecek kadar kısa dalga boyuna sahip çok yüksek frekanslı tıbbi $\mathrm{x}$-1şınlarına ve hatta gama ve kozmik ışınlara kadar değişmektedir. Bu frekans ya da dalga boyu yelpazesi elektromanyetik spektrum olarak bilinir (URL-2).

Çevremizdeki ortamda elektromanyetik dalgalar, Şekil 2'de gösterilen kesintisiz ve
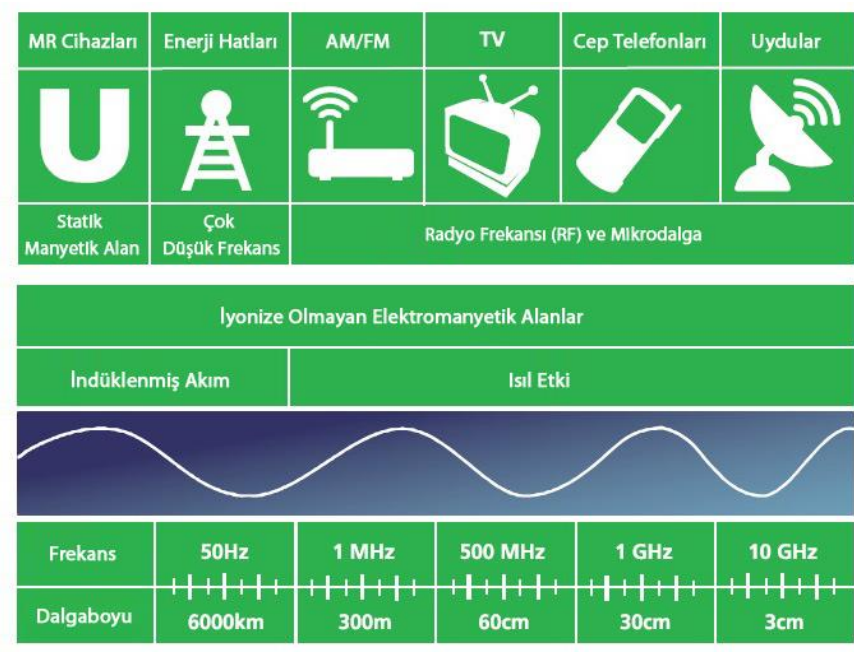

Şekil 2. Elektromanyetik spektrum (URL-4)

Figure 2. Electromagnetic spectrum (URL-4)

\section{Materyal ve Yöntem}

$\mathrm{Bu}$ bölümde önce yer ve frekans seçiminin nasıl yapıldığı verilmiş daha sonra kullanılan ölçüm detaylı olarak anlatılmış ve ölçüm yapılan cihaz hakkında teknik bilgiler verilmiştir.

\subsection{Yer ve Frekans Seçimi}

Ölçüm alanı olan Recep Tayyip Erdoğan Üniversitesi merkez kampüsü ölçüm yapıldığında altı fakülte, bir meslek yüksekokulu, iki enstitü, sosyal yaşam alanları, rektörlük ve bağlı birimlerinin yer aldığı Şekil 3 (a) da görüldüğü gibi bir yaşam alanı idi. Bu geniş enerji spektrumunu kapsar. Yelpazenin dar bir kısmını oluşturan görünür 1 şı dalgaları yaklaşık 400-700 $\mathrm{nm}$ dalga boyu aralığındadır ve duyu organları ile algılanır. Yelpazenin daha geniş kısmını kapsayan yüksek gerilim hatları, elektrikli cihazlar, radyo, televizyon, iletişim ve radar dalgaları, kızıl ötesi radyasyon ve ultraviyole radyasyon, x-1şınları, parçacık radyasyonu, gama ve kozmik 1şımalar ise duyu organları ile algılanamazlar. Literatürdeki genel kabule göre RF spektrum; $300 \mathrm{GHz}$ değerinden bölünmüş, $300 \mathrm{GHz}$ 'in altındaki RF dalgalar iyonlaştırmayan (non-ionizing), üzerindekiler de iyonlaştıran (ionizing) olarak tanımlanmıştır (URL-2, URL-3, URL-4).
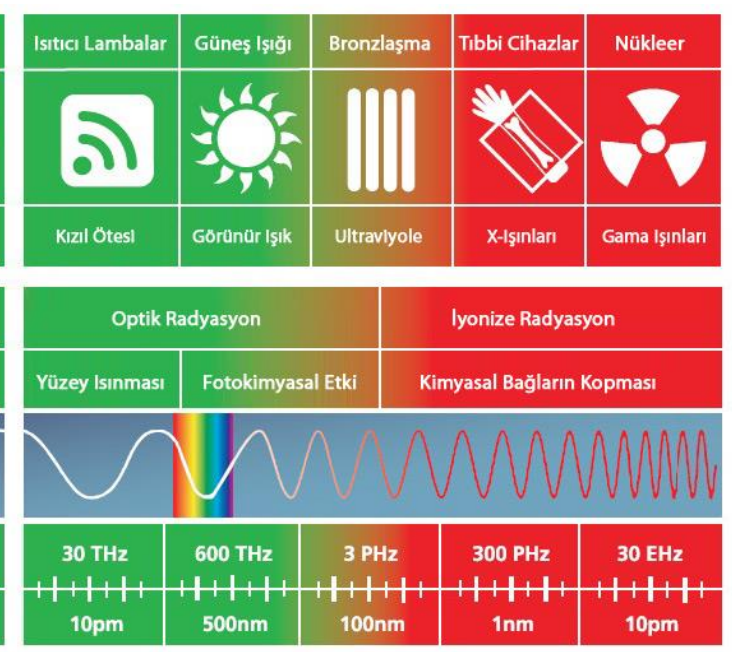

alanda yapılmış olan çalışmalarda elektromanyetik kirlilik oluşturan kaynaklara ait ölçümler alınmıştır. Kampüsün güney cephesinde yüksekçe bir tepede bulunan TVRadyo verici istasyonları ve özellikle güneybatı cephesine konumlandırılmış olan baz istasyonlarının etki alanı içinde olup kampüs dâhilinde kullanımda olan kablosuz iletişim ağları ve iletişim ve veri aktarımında kullanılan $1 \mathrm{G}, 2 \mathrm{G}$ ve $3 \mathrm{G}$ frekans bandı sinyal yoğunluğu açısından değerlendirilmesi gereken frekans bantlarıdır. Bu nedenle; elektromanyetik alan yayılımı tespit edilen elektrik alan ölçümleri, Şekil 4(b) de verilen servis tablosunda görüldüğü gibi; (470-862) MHz TV-spektrum 
band1, (890-915) MHz GSM900 UL band1, (935-946,2) MHz Operatör I servis sağlayıcı band1, (946,4-957) $\mathrm{MHz}$ Operatör II servis sağlayıcı bandı, (1710-1785) MHz GSM1800 UL band1, $(1805,2-1818,4) \mathrm{MHz}$ Operatör III DL band1, (1930-1970) için elektrik alan (E, $\mathrm{mV} / \mathrm{m}$ ) olarak nokta ölçümü yapılmıştır. Ayrıca tüm ölçümlerin etkin değeri olan toplam alan ölçümü de incelenmiştir. Her iki

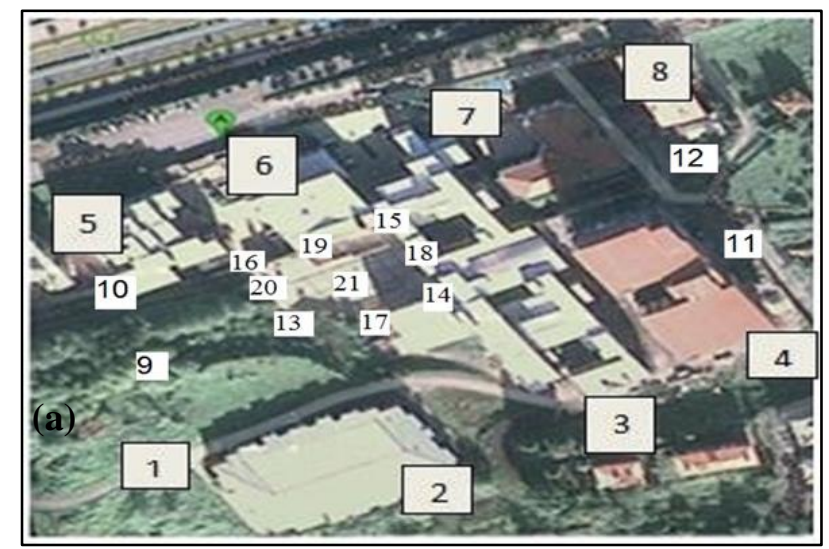

Şekil 3. (a) Kampüs krokisi, (b) ölçüm noktaları

Figure 3. (a) Campus sketch, (b) measurement points

\section{2. Ölçüm Sistemi}

Yapılan ölçümlerde Narda firmasına ait SRM 3006 cihazı kullanılmıştır. SRM 3006 (Selektif Radyasyon Metre) $9 \mathrm{kHz}$ ila $6 \mathrm{GHz}$ frekans aralığında yüksek frekanslı elektromanyetik alanların güvenlik analizlerini ve çevresel ölçümlerini yapmaya yarayan ve elde taşınarak kullanabilecek büyüklükte Şekil 4'te görüldüğü gibi bir frekans seçici elektrik ve manyetik alan ölçüm cihazıdır.
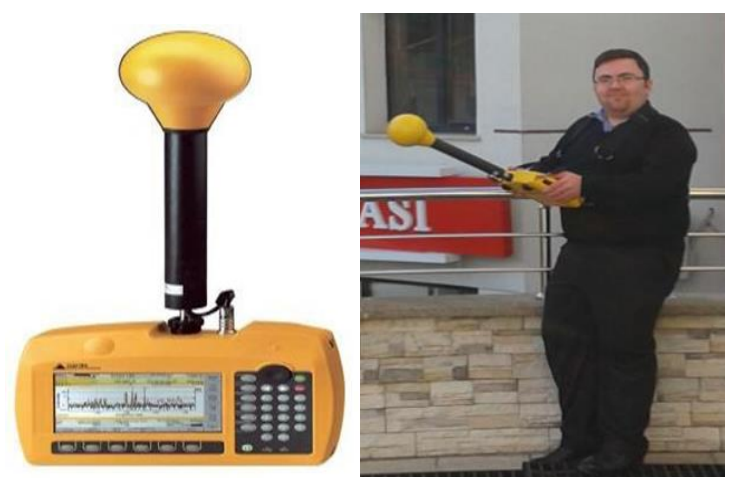

Şekil 4. SRM 3006 cihaz1 ve ölçüm görüntüsü Figure 4. View of SRM 3006 device

$\mathrm{Bu}$ büyüklükte frekansları olan sinyallerin dijital olarak örneklenmesi çok güç olduğu
(1930-1970) MHz UMTS UL band1 ve (21202170) $\mathrm{MHz}$ UMTS DL bandı için ayrı ayrı anlık ölçümlere başlamadan önce kampüsü çevreleyecek şekilde doğu, batı, kuzey, güney ve merkez hat olmak üzere Şekil 3(b) de görüldüğü gibi yaklaşı 50 'şer metre aralıklarla 21 nokta belirlenmiştir (Dilek, 2014; Özdemir, 2004).

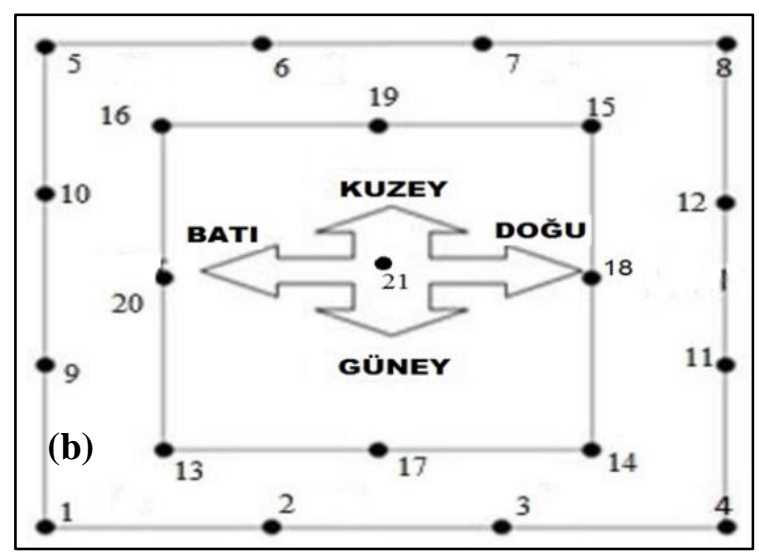

için, SRM 3006 hem analog hem de dijital sinyal işlemeyi birlikte kullanır. Radyo yayınları (AM, FM), TV yayınları (analog, DVB-T), BOS (Tetra), mobil iletişim (GSM, UMTS), radar ve kablosuz iletişim (WiMax, WLAN), gibi yüksek frekanslı elektromanyetik alanların mutlak ve sınır değerlerinin ölçümü için idealdir (NARDA, 2009; Şahin vd., 2011).

Cihazla yapılan ölçümlerde her noktanın her saat dilimindeki ölçüm için elde edilen verilerin spektrum görünümü, bilgi tablosu ve bar grafiği olmak üzere Şekil 5'teki gibi üç farklı görünümde kaydedilebilmektedir. Şekil 5(a) da spektrum görünümü verilmiş olup hangi frekans değerlerinde ortalama ve en büyük elektrik alan değerleri olduğu gözükmektedir. Şekil 5(b) de ise veri tablosu verilmiş olup belirli frekans aralıklarında en büyük alan değerleri veri tablosu olarak verilmiştir. Şekil 5(c) de ise veri tablosunda verilen değerler için elektrik alan büyüklüklerinin ortalama ve maksimum değerleri servis tablosundaki sekiz ayrı frekans bandı için bar grafiği olarak verilmiştir. 


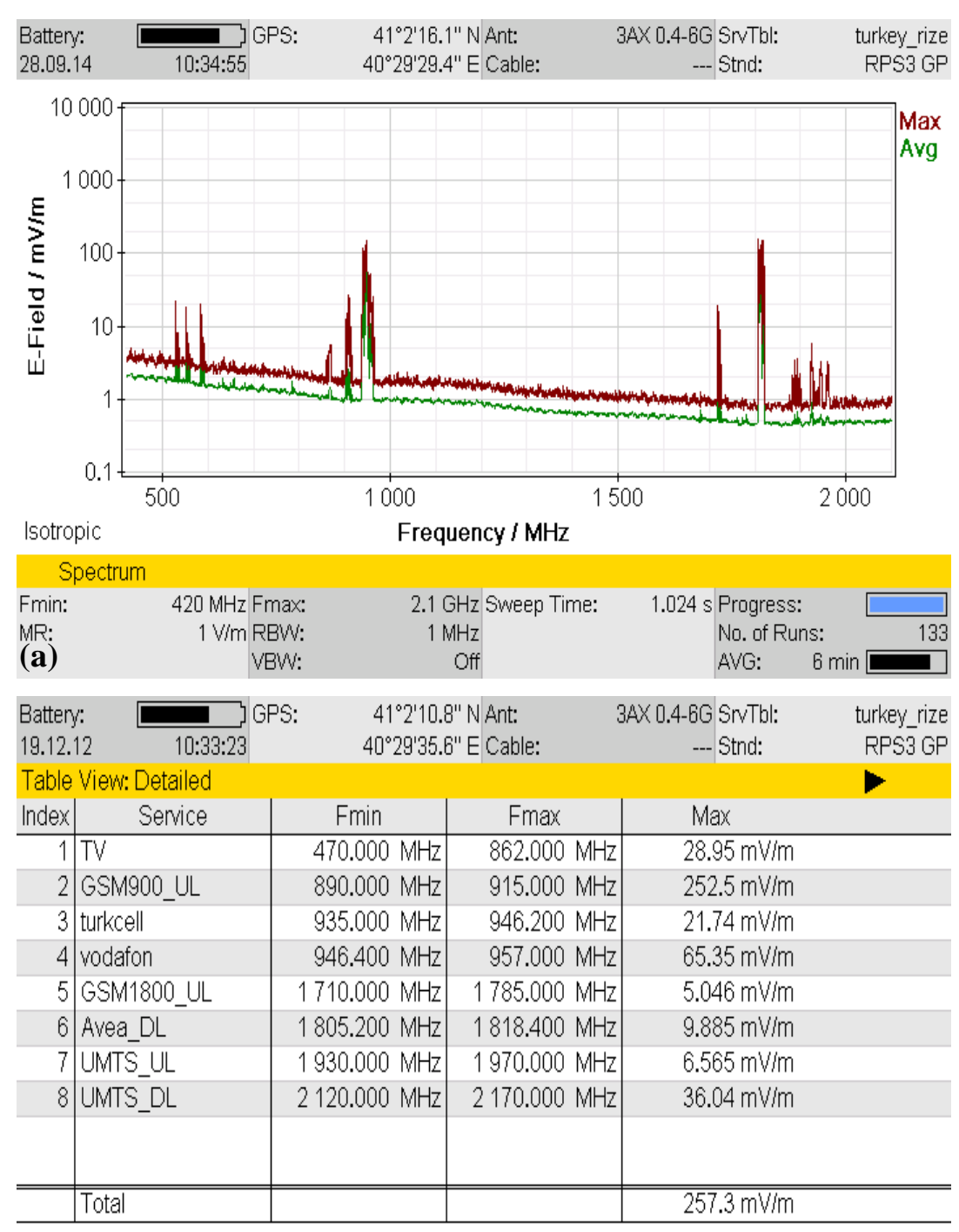

Isotropic

\begin{tabular}{|c|c|c|c|c|}
\hline \multicolumn{5}{|c|}{ Safety Evaluation } \\
\hline MR: & $1 \mathrm{~V} / \mathrm{m}$ RBW: & $\begin{array}{l}\text { Sweep Time: } \\
200 \text { kHz Noise Suppr.: }\end{array}$ & $\begin{array}{l}\text { 4.387 s Progress: } \\
\text { Off No. of Runs: }\end{array}$ & $\begin{array}{r} \\
\end{array}$ \\
\hline (b) & & & AVG: $\quad 6 \mathrm{~min}$ & $\square$ \\
\hline
\end{tabular}

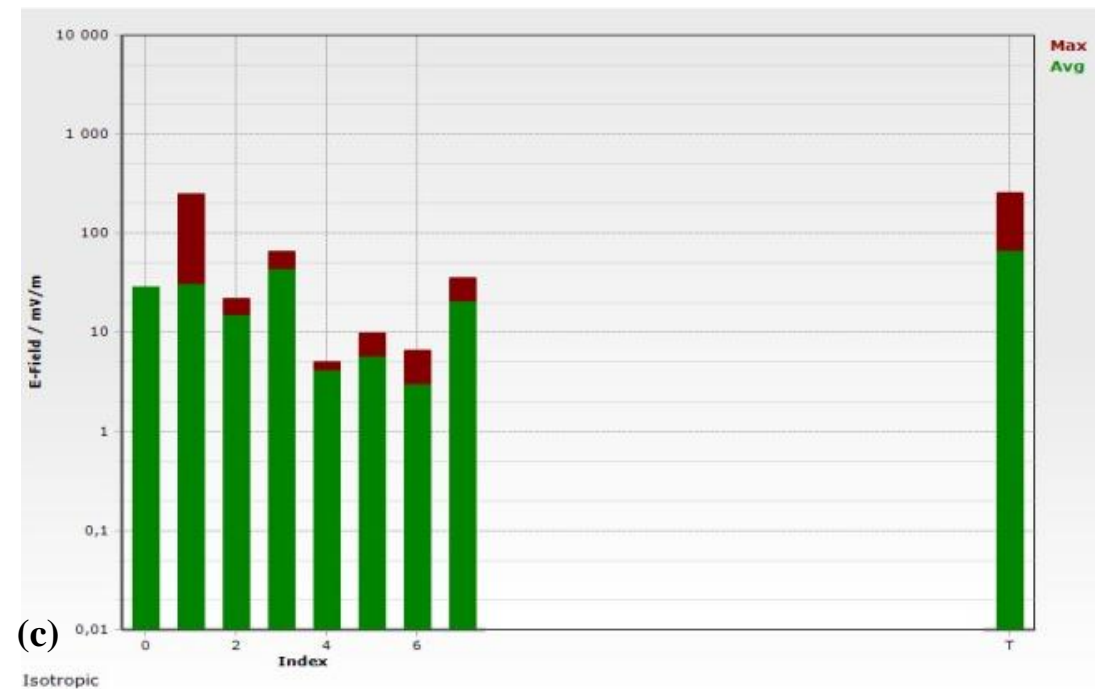

Şekil 5. (a) Spektrum, (b) veri tablosu, (c) bar grafiği görünümü

Figure 5. (a) Spectrum, (b) data table, (c) bar graph view 
Cihazın ölçüm sisteminde elektrik alan ve manyetik alan değerleri, ortalama, anlık ve maksimum olarak alınabilmektedir. Cihazın algıladığı alan değerinde doygunluğa ulaşması ve kararlı hale gelebilmesi için altı dakikalık ölçüm zamanına ihtiyaç duyulmaktadır. Bu nedenle ölçümler altı dakikalık zaman dilimlerinde gerçekleştirilmiştir. Nitekim yönetmeliklerde maruziyet süresi için belirlenen süre altı dakika olarak belirlenmiştir.

Ölçülen elektrik alan değerlerinden elde edilen veriler, MATLAB programı yardımı ile kampüse ait koordinat sistemine Tablo 1'deki noktalar için yerleştirilmiş ve üç boyutlu grafikleri elde edilmiştir.

Tablo 1. 21 ölçüm noktası için GPS koordinatları

Table 1. GPS coordinates for 21 measurement points

\begin{tabular}{lrl}
\hline Yer & Kuzey & \multicolumn{1}{c}{ Doğu } \\
\hline 1 & N 41-2-10,6 & E 40-29-34,6 \\
2 & N 41-2-12,7 & E 40-29-38,0 \\
3 & N 41-2-14,6 & E 40-29-41,0 \\
4 & N 41-2-14,4 & E 40-29-42,5 \\
5 & N 41-2-16,1 & E 40-29-29,4 \\
6 & N 41-2-17,0 & E 40-29-33,7 \\
7 & N 41-2-18,3 & E 40-29-37,2 \\
8 & N 41-2-19,1 & E 40-29-39,2 \\
9 & N 41-2-12,4 & E 40-29-31,0 \\
10 & N 41-2-13,2 & E 40-29-30,6 \\
11 & N 41-2-16,2 & E 40-29-40,5 \\
12 & N 41-2-13,9 & E 40-29-38,1 \\
13 & N 41-2-14,6 & E 40-29-36,2 \\
14 & N41-2-15,2 & E 40-29-37,1 \\
15 & N 41-2-14,9 & E 40-29-35,9 \\
16 & N 41-2-15,7 & E 40-29-35,5 \\
17 & N 41-2-15,2 & E 40-29-36,9 \\
18 & N 41-2-15,4 & E 40-29-34,5 \\
19 & N 41-2-15,7 & E 40-29-36,0 \\
20 & N 41-2-15,0 & E 40-29-36,4 \\
21 & N 41-2-15,4 & E40-29-36,2 \\
\hline
\end{tabular}

Ayrıca geliştirilen yöntemle günün farklı saatlerinde yoğun elektromanyetik kirlilik bölgelerini gösteren grafikler elde edilmiştir (Uygunol, 2009; Yomralıoğlu, 2000).

\section{Analiz ve Bulgular}

Kampüste belirlenen 21 ayrı ölçüm noktasında, günün beş ayrı saat diliminde alınan, veri tablosu ve spektrum görüntülerinin her biri yukarıda belirtildiği gibi altı dakikalık zaman dilimlerinde yapılan ölçümlerle kaydedilmiştir. Ölçümler günün yoğun olan ve olmayan saatleri düşünülerek 10:00, 12:00, 14:00, 16:00, 18:30 saatlerinde ortalama elektrik alan değerleri için alınmıştır. Ölçümlerin her bir noktaya ait elektrik alan (E) toplam değerleri spektrum bantları için ayrı ayrı tabloya aktarılmış ve günlük ortalamaları alınmıştır. Tablolara, denklem (3) ve (4)'dan Manyetik Alan (H) ve Güç Yoğunluğu (S) değerleri, hesaplanarak eklenmiştir. Tablo 2 ve 3 'te bazı spektrum bantları ve birkaç ölçüm noktasına ait tablo örnekleri özet olarak verilmiştir. Tüm ölçüm sonuçları daha önce yapılan tez çalışmasında detaylı olarak yer almaktadır (Dilek, 2014).

Ölçüm sonuçlarının ilk değerlendirmesinde, kampüs alanının kuzey-batı bölgesinde $(5,10$ ve 16 noktaları) GSM 900 ve GSM 1800 bantlarında baz istasyonlarının konumlarına bağl1 olduğu düşünülen diğer ölçümlere göre yüksek alan değerleri gözlenmiştir. Bu değerler sınır değer aralığında olup aynı zamanda anlık ölçüm zamanlarındaki kullanım yoğunluğuna da bağlı olabileceği düşünülmektedir. Kampüsün belirli noktalarında, 3G kullanım artışından ve kablosuz internet kullanımından kaynaklı olduğu düşünülen UMTS bandına ait yine kısmen yüksek değerler tespit edilmiştir. Ayrica kampüs merkezinde bulunan $(14,15$, 18 ve 19 noktaları) bilgi işlem dairesi, öğrenci kantini civarında da yer yer diğerlerine göre yüksek değerler ölçülmüştür. Ancak bunlar sınır değerlerin altındadır. 
Tablo 2. TV spektrumu verileri (470-862 MHz)

Table 2. TV spectrum data $(470-862 \mathrm{MHz})$

\begin{tabular}{|c|c|c|c|c|c|c|c|c|}
\hline \multirow[t]{2}{*}{ Yer } & \multicolumn{5}{|c|}{ Farklı Saatlerde Ölçülen E(mV/m) } & \multirow[t]{2}{*}{ Ort. E(mV/m) } & \multirow[t]{2}{*}{ Ort. $\mathbf{H}(\mathbf{m A} / \mathbf{m})$} & \multirow[t]{2}{*}{ Ort. $S\left(\mu \mathrm{W} / \mathbf{m}^{\wedge} 2\right)$} \\
\hline & 10:00 & 12:00 & $14: 00$ & 16:00 & $18: 30$ & & & \\
\hline 2 & 31,97 & 32,44 & 31,93 & 32,33 & 31,36 & 32,0060 & 0,0849 & 2,7172 \\
\hline 4 & 30,56 & 30,53 & 30,4 & 30,43 & 29,53 & 30,2900 & 0,0803 & 2,4336 \\
\hline 6 & 111,6 & 30,3 & 30,16 & 30,52 & 30,62 & 46,6400 & 0,1237 & 5,7700 \\
\hline 8 & 31,75 & 31,25 & 31,42 & 31,41 & 30,68 & 31,3020 & 0,0830 & 2,5990 \\
\hline 10 & 29,66 & 29,27 & 29,58 & 29,63 & 29,65 & 29,5580 & 0,0784 & 2,3174 \\
\hline 12 & 30,46 & 30,5 & 29,89 & 30,12 & 30,26 & 30,2460 & 0,0802 & 2,4266 \\
\hline 14 & 30,11 & 30,71 & 30,31 & 30,68 & 30,16 & 30,3940 & 0,0806 & 2,4504 \\
\hline 16 & 35,01 & 32,63 & 31,79 & 31,81 & 32,1 & 32,6680 & 0,0867 & 2,8308 \\
\hline 18 & 29,73 & 30,65 & 30,92 & 29,43 & 29,11 & 29,9680 & 0,0795 & 2,3822 \\
\hline 20 & 31,64 & 32,11 & 31,82 & 30,24 & 30,22 & 31,2060 & 0,0828 & 2,5831 \\
\hline
\end{tabular}

Tablo 3. GSM 1800_UL verileri (1710-1785 MHz)

Table 3. GSM 1800_UL data $(1710-1785 \mathrm{MHz})$

\begin{tabular}{lllllllll}
\hline Yer & \multicolumn{9}{c}{ Farklı Saatlerde Ölçülen $\mathbf{E}(\mathbf{m V} / \mathbf{m})$} & Ort. $\mathbf{E}(\mathbf{m V} / \mathbf{m})$ & Ort. H(mA/m) & Ort. S( $\left.\boldsymbol{\mu W} / \mathbf{m}^{\wedge} \mathbf{2}\right)$ \\
\cline { 2 - 5 } & $\mathbf{1 0 : 0 0}$ & $\mathbf{1 2 : 0 0}$ & $\mathbf{1 4 : 0 0}$ & $\mathbf{1 6 : 0 0}$ & $\mathbf{1 8 : 3 0}$ & & & \\
\hline 1 & 4,15 & 4,27 & 4,2 & 4,25 & 5,04 & 4,3820 & 0,0116 & 0,0509 \\
3 & 5,12 & 4,72 & 4,43 & 4,8 & 5,15 & 4,8440 & 0,0128 & 0,0622 \\
5 & 4,22 & 5,11 & 4,19 & 5,65 & 4,39 & 4,7120 & 0,0125 & 0,0589 \\
7 & 7,39 & 5,04 & 45,07 & 6,12 & 4,37 & 13,5980 & 0,0361 & 0,4905 \\
9 & 4,17 & 4,22 & 4,43 & 4,52 & 4,82 & 4,4320 & 0,0118 & 0,0521 \\
11 & 4,51 & 4,36 & 4,18 & 4,23 & 4,27 & 4,3100 & 0,0114 & 0,0493 \\
13 & 5,11 & 5,37 & 22,47 & 5,17 & 9,89 & 9,6020 & 0,0255 & 0,2446 \\
15 & 7,62 & 6,64 & 5,1 & 4,45 & 9,53 & 6,6680 & 0,0177 & 0,1179 \\
17 & 8,18 & 16,24 & 5,52 & 15,26 & 4,32 & 9,9040 & 0,0263 & 0,2602 \\
19 & 15,55 & 18,45 & 9,45 & 6,33 & 18,02 & 13,5600 & 0,0360 & 0,4877 \\
21 & 15,83 & 18,57 & 8,63 & 19,66 & 67,22 & 25,9820 & 0,0689 & 1,7906 \\
\hline
\end{tabular}

SRM-3006 cihazı ile alınan yukarıda bahsedilen noktalara ait ölçümler için tablo ve spektrum ekran görüntülerine ait örnekler Şekil 6'da verilmiştir. Şekil 6 (a)'da ölçüm yapılan GPS koordinatları, anten tipi, diğer ölçüm özellikleri ve ölçüm yapılan sekiz servis için frekans aralıkları ve ortalama değerleri altı dakikalık ölçüm sonucu için tablo olarak görünmektedir. Şekil 6 (b) de ise aynı ölçüm band1 için spektrum grafiği görülmektedir. Burada görülen pik değerleri servis tablosunda verilen çalışma aralıklarındaki servislere ait en büyük ve ortalama değerleri göstermektedir. Frekans bandı olarak $470 \mathrm{MHz}-2170 \mathrm{MHz}$ frekans bandı seçilmiştir.
SRM 3006 cihazı ile yapılan ölçümlerin yukardaki tablolarda verilen değerlerinin 21 noktaya ait en büyük ve ortalama elektrik alan değişimleri, MATLAB programı kullanılarak, Şekil 7 ve 8'de koordinat ekseninde çizilmiştir. Burada maksimim ve en büyük değerlerin özellikle belirli noktalarda daha fazla olduğu gözükmektedir. TV spektrumundaki en büyük değerler elektrik alan değerlerine göre bazı bölgelerde bir miktar fazla çıkmıştır. $\mathrm{Bu}$ bölgeler TV vericilerini doğrudan gören daha yakın bölgelerdir. 


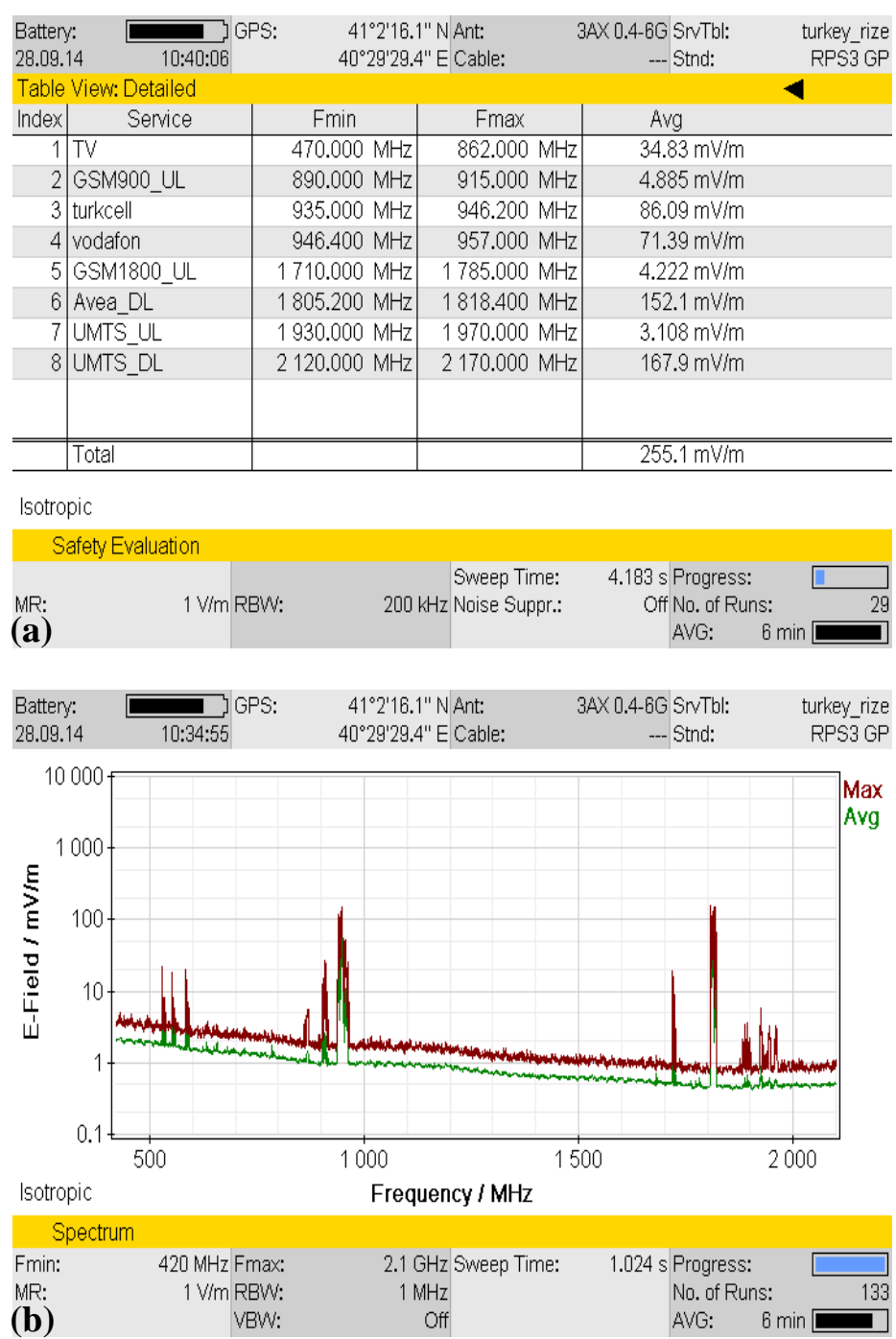

Şekil 6. Ölçüm yapılan frekans bant aralığı için, (a) Servis tablosu, (b) spektrum görüntüsü

Figure 6. For the measurement frequency bandgap, (a) Service table, (b) spectrum view

(a)

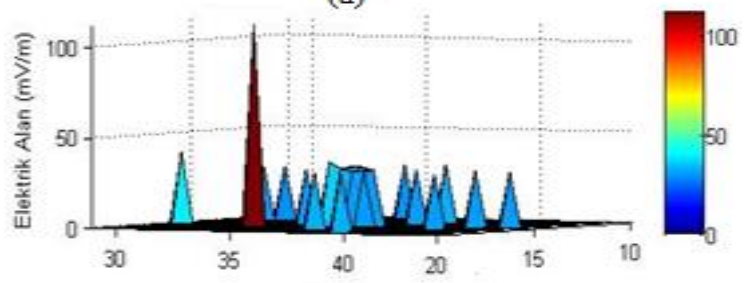

(b)

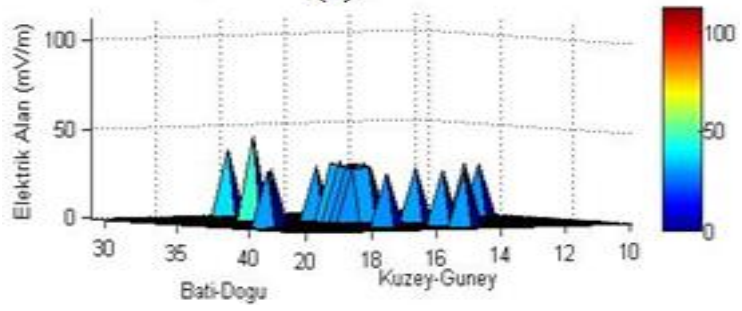

Şekil 7. Elektrik alan (a) en büyük, (b) ortalama TV spektrumu gösterimi (470$862 \mathrm{MHz})$

Figure 7. The electric field maximum (a), average (b) TV spectrum values (470-862 $\mathrm{MHz})$ (a)

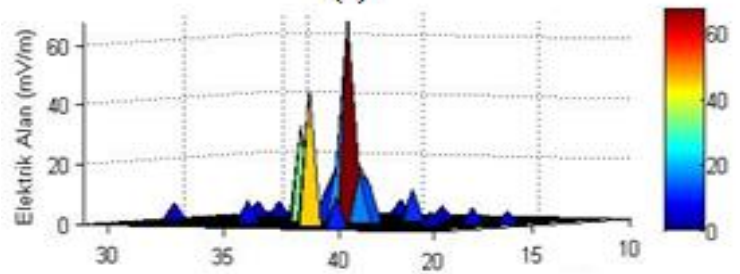

(b)

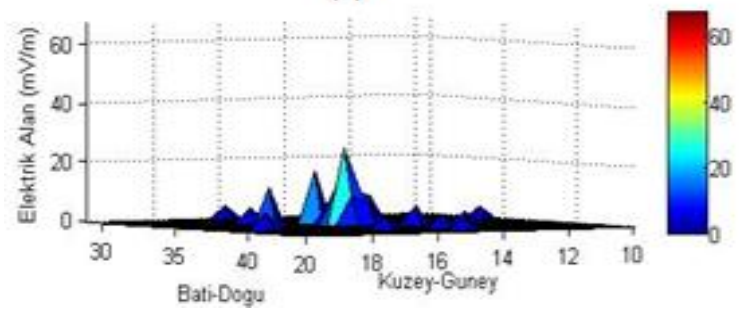

Şekil 8. Elektrik alan (a) en büyük, (b) ortalama GSM spektrumu değerleri (1710$1785 \mathrm{MHz})$

Figure 8. The maximum (a), average(b) GSM spectrum of electric fields $(1710-1785 \mathrm{MHz})$ 
Çalışma yapılan alanda her bir noktaya ait yapılan elektrik alan, manyetik alan ve güç yoğunluğu değerlerinin zamana göre değişimleri Şekil 9, 10 ve 11 'de verilmiştir. Tüm bu değerler ortalama değer olarak verilmiş ve günün beş farklı saatinde 21 ayrı noktada gerçekleştirilmiştir. Özellikle beş, on dokuz ve yirmi birince noktalarda günün tüm saatlerinde değerler yüksek görünürken altı ve on altıncı noktalarda öğle saatlerinde artış olduğu gözükmektedir.

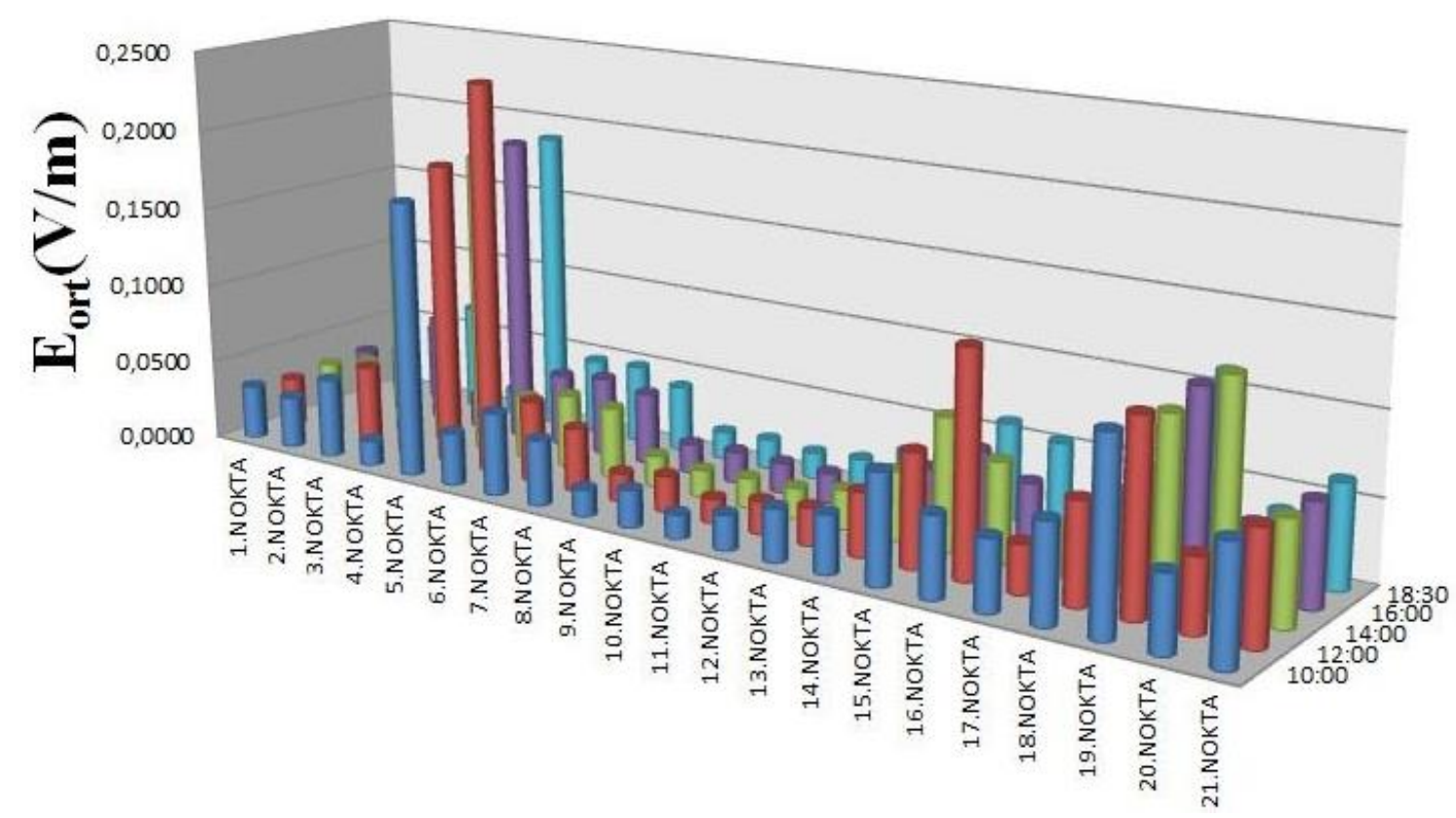

Şekil 9. Elektrik alanın ölçüm saatlerine göre farklı noktalarda değişimi

Figure 9. Change of electric field according to measurement hours for different points

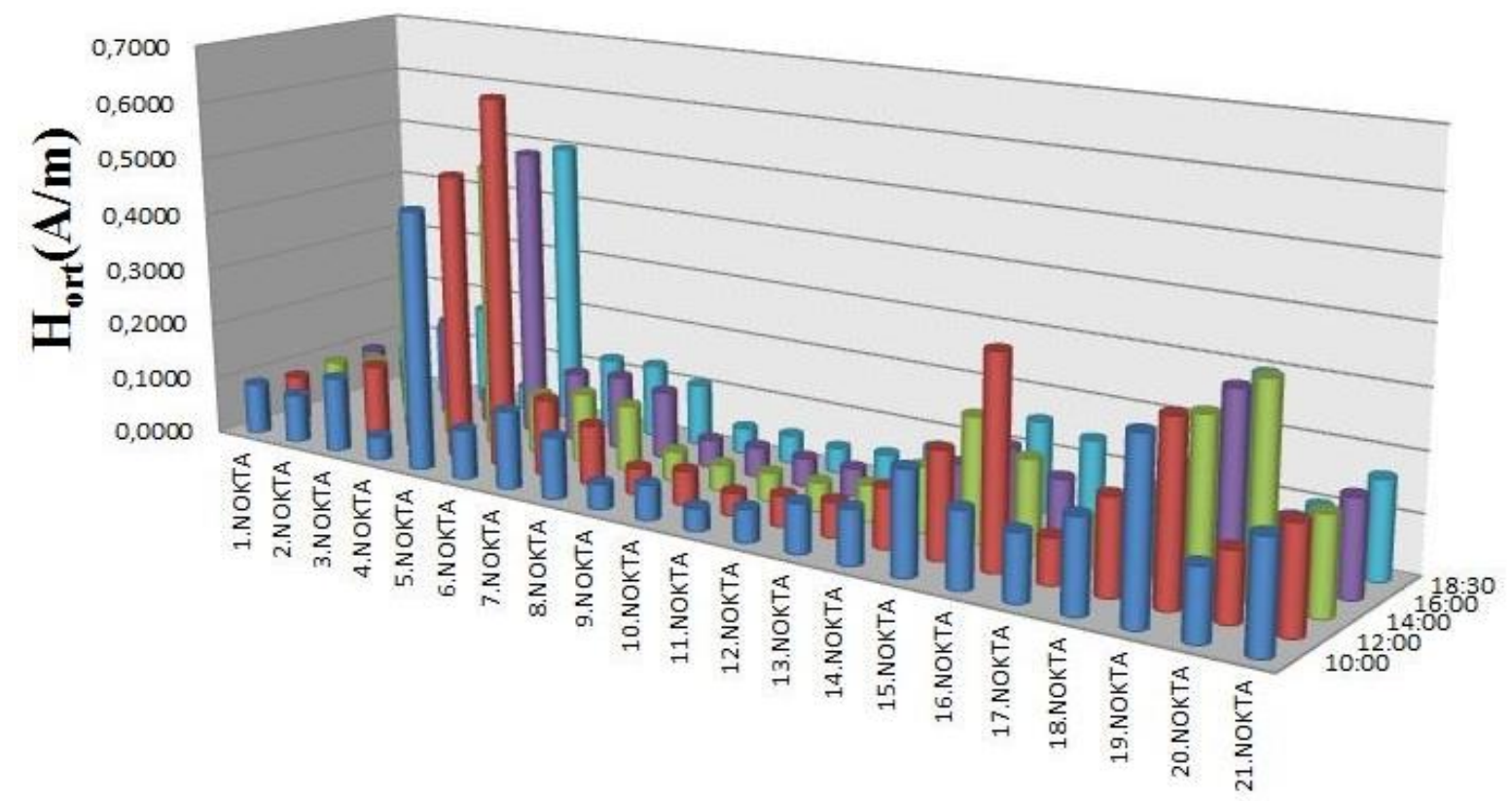

Şekil 10. Manyetik alanın ölçüm saatlerine göre farklı noktalarda değişimi

Figure 10. Change of the magnetic field according to the measurement hours for different points 


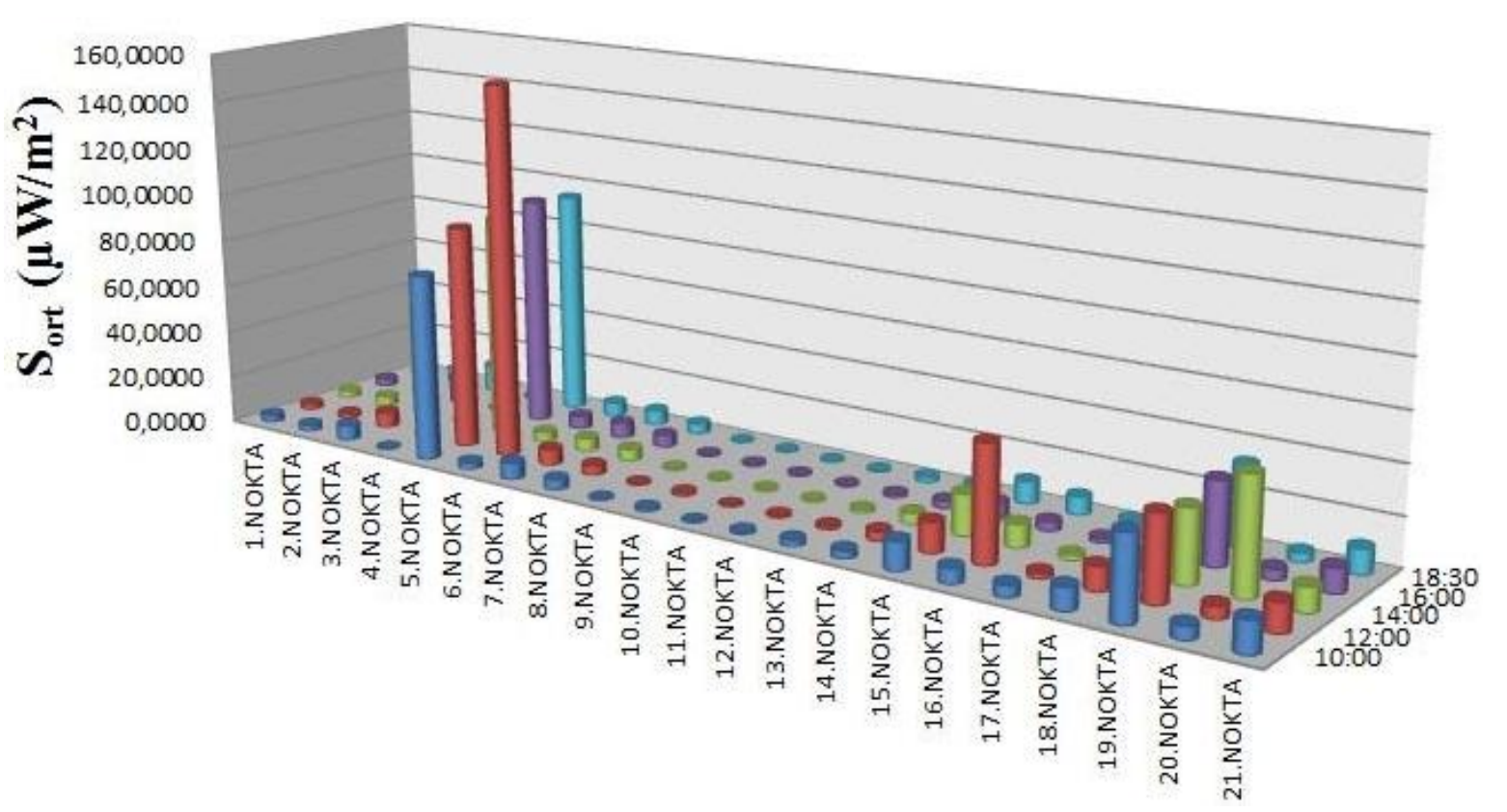

Şekil 11. Güç yoğunluğunun ölçüm saatlerine göre farklı noktalarda değişimi

Figure 11. Change of power density according to measurement hours for different points

\section{Sonuçlar ve Tartışma}

$\mathrm{Bu}$ çalışmada, üniversitemizin merkez kampüsündeki elektromanyetik kirlilik incelenmiş olup elektromanyetik kirlilik ölçümleri günün farklı saatlerinde tekrarlanarak eğitim ve sosyal aktiviteler sürecinde yoğun olarak cihazların yaydığ 1 elektromanyetik alan seviyesi analiz edilmiştir. Ölçümlerin her bir noktasına ait elektrik alan toplam değerleri spektrum bantları için ayrı ayrı tabloya aktarılmış ve gün ortalamaları alınmıştır. Tablolara, manyetik alan ve güç yoğunluğu değerleri, hesaplanarak eklenmiştir. $\mathrm{Bu}$ veriler 1şı̆̆ında, ölçüm sonuçları için şu değerlendirmeler yapılabilir:

Kampüste elektromanyetik kirliliğin en yoğun olduğu bölge 5. ölçüm noktası ve çevresinde 6 . ve 10. noktalar olup lojmanlara yakın olmasının etkisiyle her ölçüm saatinde diğerlerine göre daha yüksek değerler tespit edilmiştir. 7. ve 19. noktalar kütüphane, öğrenci işleri ve daire başkanlıklarının bulunduğu yerler olup değerlerin diğerlerine göre bir miktar yüksek olduğu diğer noktalardır. Ayrıca, kantin ve Bilgi İşlem Daire Başkanlığ1 civarındaki 18., 13., 20. ve 21. noktalar da öğrenci yoğunluğu, serbest dolaşım ve veri aktarımın yoğun olduğu bölgeler arasındadır. $\mathrm{Bu}$ bölgelerde de kayda değer miktarda elektromanyetik kirlilik olduğu tespit edilmiştir. Kampüsün yan çevrelerini temsil eden 9., 10., 11. ve 12. noktalar arasinda ise elektromanyetik kirlilik yok denecek kadar azdir.

Kampüste yapılan tüm ölçümlerin sonucunda elde edilen değerlere göre, bölgesel olarak alan değerlerinde dalgalanmaların ve artışın gözlendiği bölgeler de vardır. Fakat yine de anlık olarak en büyük değerler yakalansa da ortalamaya bakıldığında, tüm ölçümler sınır değerlerin altında kalmaktadır. En yüksek değerlerin bulunduğu kuzey-batı bölgesinde ise kampüsümüze yakın bölgede bulunan baz istasyonu ve vericilerin etkili olduğu düşünülmektedir.

Sonuç olarak, yapılan ölçümlerden alınan elektromanyetik alan değerlerinin bir miktar yüksek olduğu bölgeler tespit edilse de bu değerler BTK'nın belirlediği limitlerin altındadır. Kampüste yoğun olarak kullanılan WLAN, Bluetooth, GSM, baz istasyonları gibi elektromanyetik alan kaynaklı kirliliğin, yayılımın yoğun olduğu bölgelerde öğrenci ve personelin üzerinde olumsuz etki oluşturacağı 
düşünülmektedir. $\mathrm{Bu}$ bağlamda teknolojik cihazları kullanırken yaydıkları radyasyondan en az etkilenmek için sürekli maruziyet azaltmak ve cihazlara olan mesafeyi artırmak gibi birtakım tedbirlerin alınması gerekmektedir.

\section{Teşekkür}

Çalışmanın gerçekleştirilmesinde Recep Tayyip Erdoğan Üniversitesi Elektromanyetik Uygulama ve Araştırma Merkezindeki (REMAM) mevcut cihazlar ve daha önce RTEÜ BAP birim tarafindan desteklenen PN:2013.102.01.1 numaralı proje altyapis1 kullanılmıştır. Yazarlar REMAM ve BAP birimine teşekkür ederler.

\section{Author's ORCID ID}

Nilüfer As, 0000-0003-2026-4014

\section{Kaynaklar}

Ada, N. (2007). Örgütsel iletişim ve yeni bilgi teknolojileri; örgütsel iletişim ağları, Ege Academic Review, 7(2), 543-551.

As, N., Dilek, B., Şahin, M.E., Karan, Y. (2014). Electromagnetic pollution measurement in the RTE university campus area, Global Journal on Advances Pure and Applied Sciences, 3, 65-72.

As, N., Dilek, B., Şahin, M.E., Karan Y. (2014). Electromagnetic Pollution Measurement in the RTE University Campus Area, 2nd Global Conference on Enrivonmental Studies, 10.04.2014, Roma, İtalya.

Bailey, W. H., Bodemann, R., Bushberg, J., Chou, C. K., Cleveland, R., Faraone, A., ... \& Zollman, P.M. (2019). Synopsis of IEEE Std C95. 1 ${ }^{\text {TM }}$ 2019 "IEEE Standard for Safety Levels with Respect to Human Exposure to Electric, Magnetic, and Electromagnetic Fields, $0 \mathrm{~Hz}$ to 300 GHz”. IEEE Access, 7, 171346-171356.

Baysal, U. (2011). Elektromanyetik alanların sağlık etkilerinin değerlendirilmesi. Elektromanyetik Alanlar ve Etkileri Sempozyumu (258-261), Ezgi Matbaacılık, İstanbul.

Bold, A., Toros, H. ve Şen O. (2003). Manyetik alanın insan sağlığı üzerindeki etkisi, III. Atmosfer Bilimleri Sempozyumu, 19-21 Mart, İstanbul, Türkiye, 62-68.

Bursa Nilüfer Belediyesi, (2007). Nilüfer ilçesi elektromanyetik kirlilik raporu 2007, Bursa,
Türkiye.

Dilek, B. (2014). Recep Tayyip Erdoğan Üniversitesi merkez kampüs alanının elektromanyetik kirlilik haritasının çıkarılması, Yüksek lisans tezi, Recep Tayyip Erdoğan Üniversitesi, Fen Bilimleri Enstitüsü, Türkiye.

Dilek, B., As, N., Şahin, M.E. (2013). RTE Üniversitesi merkez kampüs güney hattı boyunca elektromanyetik kirlilik ölçümü, EMANET 2013, İstanbul, Türkiye.

Güler, Ç., Çobanoğlu, Z. (1994). Elektromanyetik radyasyon, Sağlık Bakanlığı Yayınları, Ankara.

Hamid, R., Çetintaş, M., Kunter, F., Karacadağ, H. (2006). Elektromanyetik kirlilik ve GSM baz istasyonları ve 1şınımların ölçülmesi, Kent ve Sağllk Sempozyumu, Bursa, Türkiye.

ICNIRP, (1998). Guidelines for limiting exposure to time varying electric, magnetic, and electromagnetic fields (up to $300 \mathrm{GHz}$ ), Health Physics, 74(4), 494-522.

Kamil, Ç. (2006). Elektromanyetik alan, Bilim ve Teknik Dergisi, Ağustos Sayısı.

Karadağ, T, Özdemir, A, Abbasov, T. (2014). Seçilmiş bir pilot bölgede uzun süreli ve sürekli elektromanyetik kirlilik seviyelerinin ölçülmesi ve haritalanması. Gazi University Journal of Science Part C: Design and Technology, 2(3), 239-246.

Karan, Y., As, N. (2016). Electromagnetic radiation measurement of high power wireless network adapter, Turkish Journal of Electromechanics Energy, 1(2), 17-23.

Karan, Y., As, N., Şahin, M.E. (2017). Investigation of GSM, LTE and Wi-Fi electromagnetic radiation in dwellings, Acta Physica Polonica A, 132(3), 509-512.

Kılıç, M.A., Çerezci O., Çevik Ö., Kalkan T. (2011). Cerrahpaşa Tip Fakültesinin elektromanyetik alan haritası. EMANET, 1, 247250.

NARDA, (2009). Basic Insights Safety in electric, magnetic and electromagnetic fields, Technical Document, Germany, 1-20.

Özdemir, A.R. (2001). Elektromanyetik dalgaların yayılımı ve dönüşüm formülleri, Telekomünikasyon Kurumu Spektrum İzleme ve Denetleme Daire Başkanlığı, 34 s., Ankara.

Özdemir, A. R. (2004). Ankara İstanbul ve İzmir şehirlerinde elektromanyetik kirlilik haritasının hazırlanması ve elektromanyetik kirliliğin azaltılması yönünde öneriler, Uzmanlık Tezi, Telekomünikasyon Kurumu, 125 s., Ankara.

Özgür, A., Tümkaya, L., Terzi, S., Kalkan, Y., 
Erdivanl1, Ö.Ç., Dursun, E. (2015). Effects of chronic exposure to electromagnetic waves on the auditory system. Acta Oto-Laryngologica, 135(8), 765-770.

Şehitoğlu, I., Tümkaya, L., Kalkan, Y., Bedir, R., Cure, M.C., Zorba, O.U., Cure, E., Yüce, S. (2015). Biochemical and histopathological effects on the rat testis after exposure to electromagnetic field during fetal period, Arch. Esp. Urol, 68(6), 562-568.

Sevgi, L. (2000). Electromagnetic compatibility and electromagnetic pollution, TMMOB Electrical Engineering Society, İstanbul Department Publishing Series, 320.

Sevgi, L. (2000). EM kirlilik, cep telefonları ve baz istasyonları, EMO Ístanbul Şube Bülteni, Haziran.

Söğüt, Ö., Karadeniz, Ş. (2017). Measurement of electromagnetic pollution in Adiyaman city centre. Adlyaman Üniversitesi Fen Bilimleri Dergisi, 7(1), 89-108.

Şahin, M.E., Karan, Y., As, N. (2013). Selective radiation measurement for safety evaluation on base stations, Gazi University Journal of Science, 26(1), 73-83.

Şahin, M.E., Karan, Y., As, N. (2011) Spectrum analyzer measurement technique for safety evaluation on wireless communication systems, IEEE Proceeding URSIGASS 2011, İstanbul.

Şahin, Ö. (2016). Measurement of Electromagnetic Field Strength in the Centre of Kahramanmaraş and Its the Mapping (Doctoral dissertation, M. Sc. Thesis, KSÜ, Institute of Science and Technology, Bioengineering Sciences Department, Kahramanmaraş).

Şeker, S., Çerezci O. (2000). Radyasyon kuşatması, Boğaziçi Üniversitesi Yayınevi, İstanbul, 1-26.

Taktak, F., Tiryakioğlu, I., \& Yilmaz, I. Gps'de kullanılan elektromanyetik dalgaların insan sağlığına etkilerinin irdelenmesi. Istanbul Teknik Üniversitesi, Mühendislik Ölçmeleri STB Komisyonu 2. Mühendislik Ölçmeleri Sempozyumu, 23-25 Kasim 2005, İTÜ İstanbul.

T.C. Resmi Gazete, (2001). $10 \mathrm{kHz}-60 \mathrm{GHz}$ frekans bandında çalışan ve ortamda istem dış1 elektromanyetik alan maruziyetine neden olan sabit telekomünikasyon cihazlarının kuruluş yeri, montaj1, elektrik alan şiddeti limit değerlerinin belirlenmesi, ölçüm yöntemleri ve denetlenmesi hakkında yönetmelik, Ankara, Türkiye.

T.C. Resmi Gazete. (2009). Elektronik haberleşme cihazlarına güvenlik sertifikası düzenlenmesine ilişkin yönetmelik, Sayısı: 27230, Ankara, Türkiye.

T.C. Resmi Gazete. (2011). Elektronik haberleşme cihazlarından kaynaklanan elektromanyetik alan şiddetinin uluslararası standartlara göre maruziyet limit değerlerinin belirlenmesi, kontrolü ve denetimi hakkında yönetmelik, Sayısı: 27912, Ankara, Türkiye.

T.C. Resmi Gazete. (2018). Elektronik haberleşme cihazlarından kaynaklanan elektromanyetik alan şiddetinin uluslararası standartlara göre maruziyet limit değerlerinin belirlenmesi, kontrolü ve denetimi hakkında yönetmelikte değişiklik, Sayısı: 30394, Ankara, Türkiye.

TS ENV 50166-2 (1996). İnsanların elektromanyetik alanlara maruz kalması-yüksek frekanslar $(10 \mathrm{kHz}-300 \mathrm{GHz})$. TSE Standardı, Ankara.

URL-1, (2000). GSM (Global System for Mobile Communications), http://www.antrak.org.tr /gazete/032000/mutlu.htm, 29.03.2014.

URL-2, (2020). http://gnrk.gazi.edu.tr/posts/view /title/sar-nedir\%3F-10102, 8 Kasim 2020.

URL-3, (2020). http://remam.idari.erdogan.edu.tr/, 8 Kasim 2020.

URL-4, (2020). Electromagnetic Spectrum, https://www.demos.com.tr/en/brand/electrosens e_emr_olcumu/, 8 Kasim 2020.

Uygunol, O. (2009). Coğrafi bilgi sistemi yardımıyla GSM baz istasyonlarında elektromanyetik alan kirliliği tespiti ve Konya örneği, Yüksek Lisans Tezi, Selçuk Üniversitesi Fen Bilimleri Enstitüsü, Konya, Türkiye.

Yomralıŏlu, T. (2000). Coğrafi bilgi sistemleri temel kavramlar ve uygulamalar, Akademi Kitabevi, Trabzon. 